\title{
CENAS DA ESCRAVIDÃO: ASPECTOS DA VIDA COTIDIANA DOS ESCRAVOS DE GRANDES CIDADES NO BRASIL OITOCENTISTA
}

\section{SCENES OF SLAVERY: \\ ASPECTS OF EVERYDAY LIFE OF SLAVES FROM LARGE CITIES IN BRAZIL IN THE NINETEENTH CENTURY}

Dimas José Batista ${ }^{1}$

Resumo: O artigo analisa imagens produzidas no século dezenove por viajantes e artistas brasileiros e estrangeiros que retrataram a vida cotidiana de escravos em grandes cidades procurando captar as práticas sociais vividas pelos escravos. Não é um trabalho exaustivo, sistemático sobre a produção artística dos desses artistas oitocentistas, mas revela aspectos valiosos da vida dos cativos. Objetivamos neste estudo exploratório anotar algumas ideias e fazer algumas reflexões sobre o modus vivendi dos escravos na Corte do Rio de Janeiro durante o século XIX. Não é o olhar do historiador da arte, mas do historiador do escravismo, da cultura, da história social.

Palavras-chave: literatura de viajantes; iconografia; vida cotidiana; escravidão; Brasil

Abstract: The article analyzes images produced in the nineteenth century by travelers and Brazilian and foreign artists who portrayed the daily lives of slaves in large cities seeking to capture the social practices experienced by slaves. It is not an exhaustive, systematic work on the artistic production of these 19th century artists, but it reveals valuable aspects of the lives of the captives. In this exploratory study we aim to write down some ideas and reflect on the modus vivendi of slaves at the Court of Rio de Janeiro during the 19th century. It is not the look of the art historian, but the historian of slavery, culture, social history.

Keywords: traveler literature; iconography; everyday life; slavery; Brazil.

\section{0 universo social do trabalho: sobrevivência e convivialidade}

O escravo era a principal ferramenta, instrumento e força de trabalho utilizada durante o século XIX. A historiografia da escravidão é unanime em afirmar que, desde o período colonial, "os escravos são as mãos e os pés do senhor do engenho, porque sem eles no Brasil não é possível fazer, conservar e aumentar fazenda, nem ter engenho corrente."(ANTONIL, 1982, p. 31). De fato, os escravos realizavam como força de trabalho todo o tipo de atividade produtiva - individual ou coletiva, social ou familiar. Não só a historiografia acadêmica insiste que os escravos exerciam todo o tipo de trabalho manual ou qualquer outro, mas a literatura de

\footnotetext{
${ }^{1}$ Doutor em História. Prof. Adjunto III do Colegiado do Curso de Licenciatura em História da UFT. E-mail: dimas@uft.edu.br
} 
viagem produzida na época retratou com abundancia os escravos executando diversos tipos de atividade laborais. Neste breve artigo, iremos refletir sociológica, histórica, antropológica e culturalmente sobre as imagens construídas a respeito da presença de escravos e escravas em espaços públicos e privados durante o século dezenove no Brasil, a partir do olhar dos viajantes estrangeiros (BELLUZO, 1985).

O escravo - homem ou mulher - circulava por diversos espaços e se dedicava às mais diversas atividades na vida social brasileira. As imagens produzidas pelos viajantes estrangeiros, à par da visão etnocêntrica e eurocêntrica, permitem entrever alguns flash's da cultura e do modo de vida dos escravos, especialmente na cidade do Rio de Janeiro do início do século XIX. É possível refletir sobre os costumes - hábitos de vestir, comer, se divertir, o sentimento da morte, da caridade e tantos outros aspectos da vida cotidiana dos africanos e seus descendentes, retratados pelos viajantes estrangeiros que viveram, passaram e/ou trabalharam na capital do império.

As inúmeras dimensões da vida cotidiana, pública e privada, dos cativos - a da solidariedade, da intimidade, da privacidade, da convivialidade, da civilidade - emergem nas representações feitas em gravuras, desenhos, litogravuras, pinturas e outras manifestações artísticas produzidas no período. O conceito de representação (CHARTIER, 2002) é fundamental para entendermos essa produção artística bem como o conceito poder simbólico (BOURDIEU, 1989). Mas, antes de nos atermos ao conceito de representação, vejamos um conjunto de imagens que retratam o escravo no mundo do trabalho e no mundo do lazer, do entretenimento e das festividades:

Fig. 1 - Ama de Leite

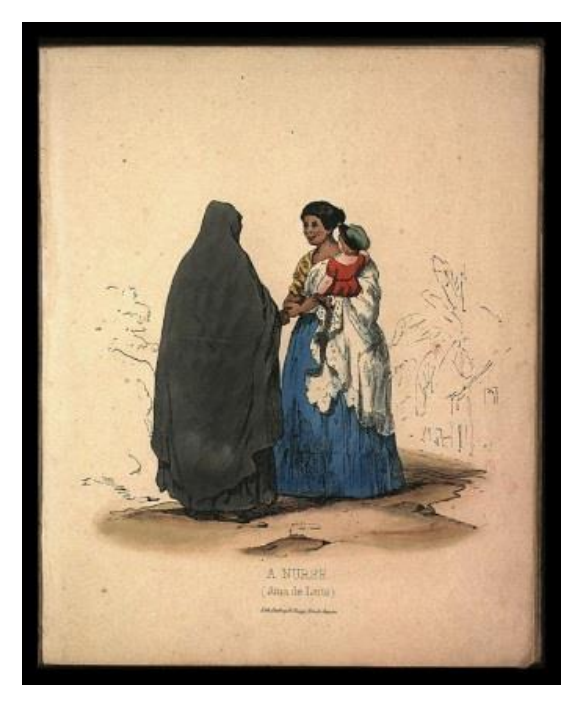


Fonte:http://bndigital.bn.gov.br/projetos/escravos/galeriagravuras.html Acesso em 07 ago 2017

Fig. 2. Carregadores de água

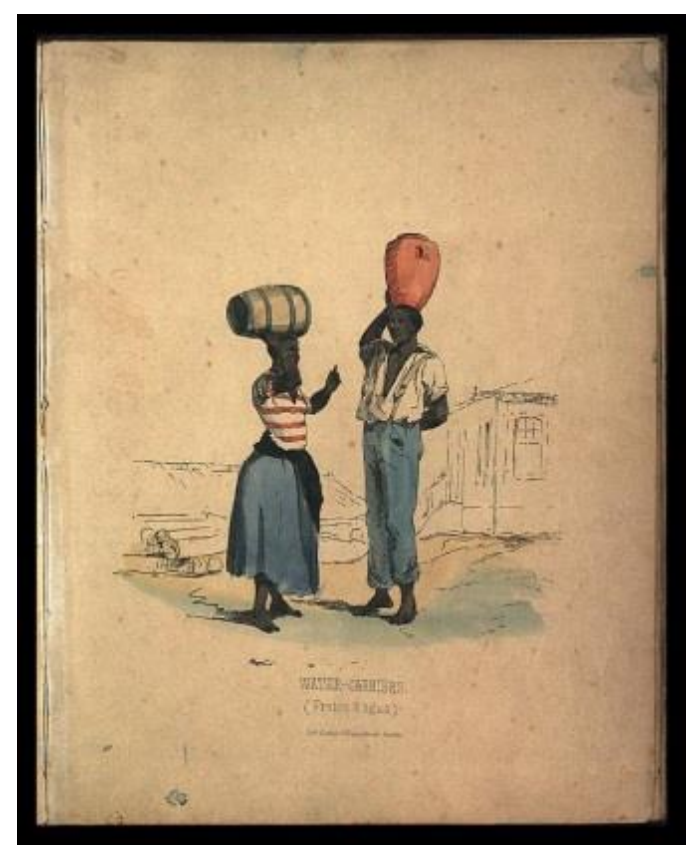

Fonte:http://bndigital.bn.gov.br/projetos/escravos/galeriagravuras.html Acesso em 07 ago. 2017

Notamos inicialmente, a presença da mulher nas duas imagens. No entanto, na fig. 1., a mulher executa um trabalho "tipicamente" feminino a amamentação, enquanto, na fig. 2., a mulher executa uma tarefa vinculada ao uso da força física como carregadora de água. As duas imagens pertencem ao mesmo acervo iconográfico. Provavelmente, se estivéssemos fazendo pesquisa acerca da origem, procedência, exatidão da data de produção, autoria, estilo, cores, formas e outras características especificas do campo da historia da arte teríamos que nos preocupar com desvendar quem produziu a "pintura", mas essa não é a intenção explicita aqui. Objetivamos neste estudo exploratório anotar algumas ideias e fazer algumas reflexões sobre o modus vivendi dos escravos na Corte do Rio de Janeiro durante o século XIX. Não é o olhar do historiador da arte, mas sim do historiador do escravismo, da cultura, da história social. Tenho plena consciência das possíveis criticas que isso implica, mas estou disposto a correr o risco.

As imagens nos permitem infiltrar na vida cotidiana do século dezenove, cheia de encanto e magia, compensando o risco e aliviando as incertezas do caminho. As imagens expostas acima demonstram que não havia um "sexo frágil” no século XIX, não para as mulheres escravas - carregadoras, vendedoras ambulantes, amantes, amas de leite, mucamas, enfim, "pau para toda obra" - que exerciam todo o tipo de atividades econômicas na maior 
metrópole do império. Estas mulheres viviam com toda intensidade os espaços públicos e privados. Mas, havia diferenças visíveis entre elas: na fig. 1., vemos uma mulher trajando um vestido de melhor qualidade do que o daquela que trajava a mulher da fig. 2, inclusive, sabemos que ela está descalça. Isso, de fato, revela que a ama de leite, provavelmente, enfrentaria condições de trabalho menos degradantes do que a da carregadora de água. Ao menos do ponto de vista da atividade laboral, pois as duas eram mulheres escravas num mundo hostil.

Os escravos trabalhavam para sobreviver. Lutavam dia-a-dia pelas coisas mais simples necessárias à manutenção de suas vidas: comida, roupas, abrigo e saúde. A luta diária pela manutenção da vida implicava se sujeitar às mais difíceis e degradantes atividades laborais. Obviamente que as atividades econômicas que cada sexo exercia não podem ser vista como iguais, mesmo porque embora as mulheres escravas realizassem diversas tarefas árduas não poderiam ser comparadas aos homens. Vejamos alguns exemplos que elucidam parte da questão:

Fig. 3. Negros serradores

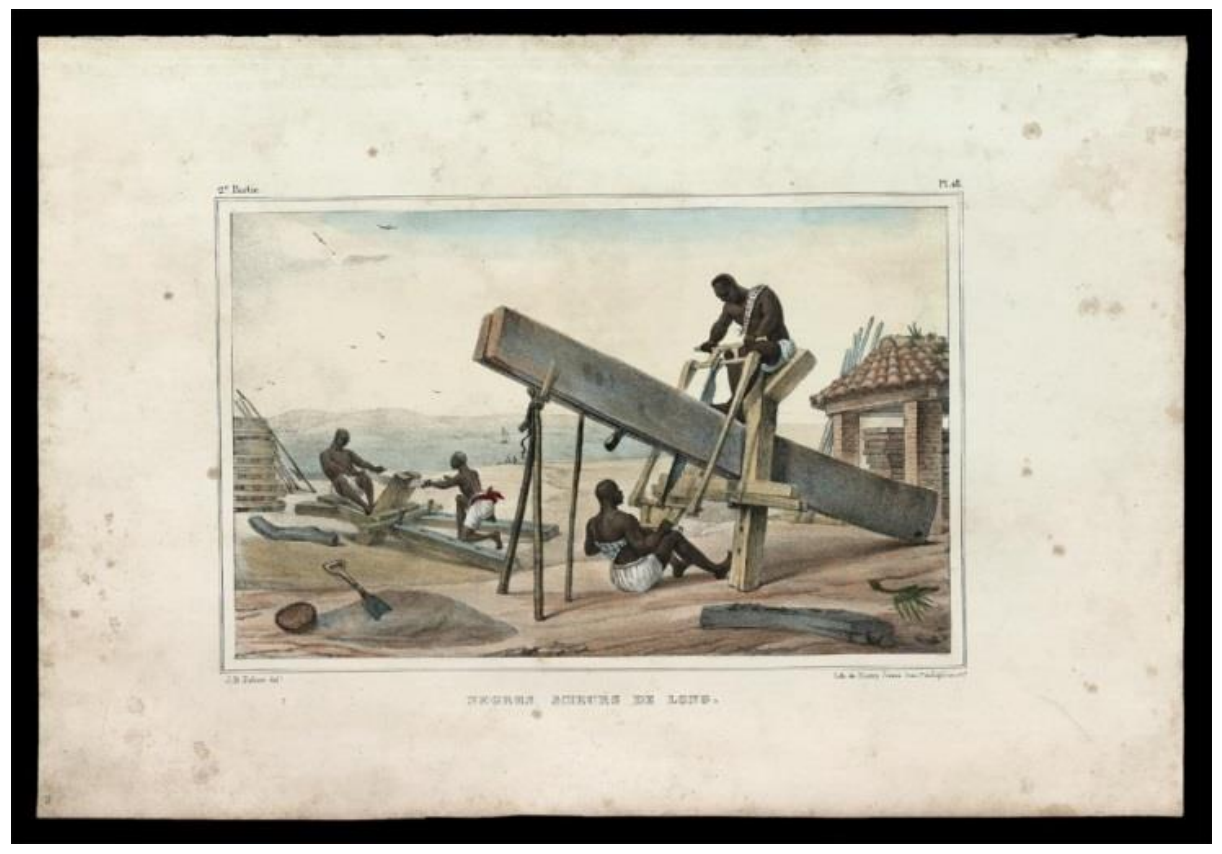

Fonte:http://bndigital.bn.gov.br/projetos/escravos/galeriagravuras.html Acesso em 07 ago. 2017

A imagem acima: a) somente homens. b) utilizando instrumentos cortantes e realizando o corte da madeira para, provavelmente, construir casas, embarcações ou qualquer outra construção de grande porte. c) nota-se que atividade de risco, que exige grande força física e isso se vê pela constituição física dos homens que realizam a atividade laboral. Esses 
marceneiros, carpinteiros ou construtores poderiam ser mulheres, talvez, mas pela atividade exercida muito pouco provável que os senhores de escravos aplicassem mulheres nesse tipo de trabalho. Os instrumentos utilizados exigem força física - peneiras, pás, serrotes, enfim, era uma atividade que poderia ser realizada por mulheres, mas com frequência foram realizadas por trabalhadores escravos masculinos.

O universo do trabalho revela uma operacionalidade, uma racionalidade e um sistema de exploração do trabalho do homem e da mulher em campos diferenciados. Os escravos carregadores de cadeirinhas mostram claramente essa diferenciação/especialização da atividade laboral no século XIX, eles estão ricamente vestidos e a própria cadeirinha é um transporte de luxo. Vejamos alguns tipos de trabalhadores que eram explorados, mas tinham um estatuto no mundo do trabalho um pouco menos degradante do que a maioria dos trabalhadores escravos que lutavam pela sobrevivência na cidade do Rio de Janeiro durante o século XIX:

Fig. 4. Carregadores de cadeirinha

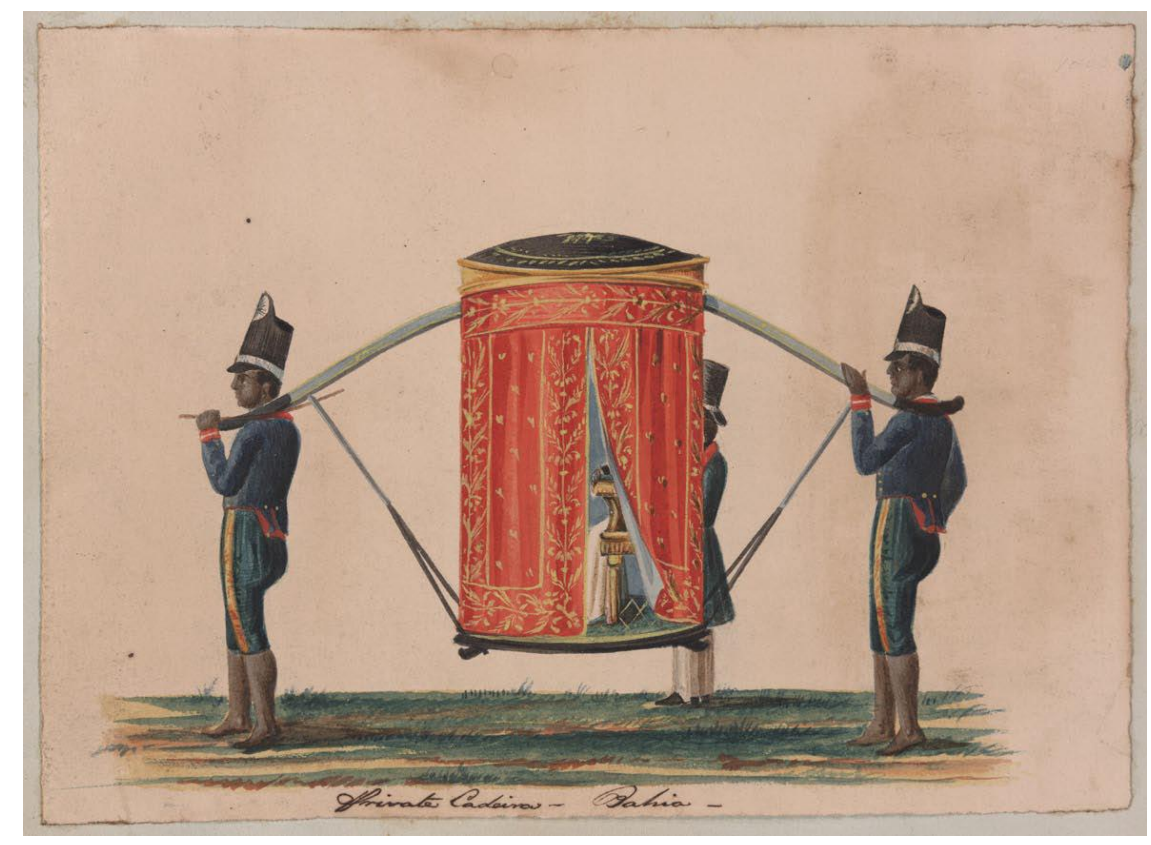

Fonte:http://bndigital.bn.gov.br/projetos/escravos/galeriagravuras.html Acesso em 07 ago. 2017

A riqueza de detalhes desta imagem exige que façamos uma breve descrição. Dois homens aparecem carregando a cadeirinha. Esse era um tipo de transporte privativo de certas damas da elite carioca, embora fosse relativamente comum, nem todos podiam usufruir desta comodidade e da privacidade desse transporte. Comodidade porque protegido do sol, da chuva e da poeira das ruas sem calçamento da Corte. Privacidade, pois a cadeirinha está encoberta por 
um tecido aparentemente de seda, camurça ou cetim que impede que seu viajante seja incomodado ou mesmo conhecido, há o ocultamento ou preservação da intimidade do viajante. Notamos ainda que os carregadores estão uniformizados o que os destaca da multidão e de outros trabalhadores braçais escravos.

O exemplo seguinte era um pouco mais sofisticado e, evidencia outra gradação social. Agrega-se nesta imagem a força de trabalho dos escravos como condutores e cocheiros e a força motriz dos cavalos. Sofistica-se a forma de transporte. Amplia-se a possibilidade de carregamento e, em consequência, de demonstrar poder e status social. O transporte e os seus condutores são os sinais externos visíveis da ostentação e do luxo. A igreja, e seus serventuários, o clero não que se equipar, se nivelar com o restante da população - classe média urbana nascente, nem tão pouco com a pequena burguesia incipiente existente na capital politica e econômica do império brasileiro. A Igreja e o clero são os representantes de Roma na sociedade brasileira e se portavam com a dignidade esperada pelos governantes da época.

Essas imagens não retratam apenas o cotidiano da cidade. Elas não representam apenas as atividades e a luta diária dos seus habitantes, vão além: descortinam as relações sociais e demonstram os aspectos de convivialidade, intimidade e privacidade dos homens e mulheres poderosos da época bem como de homens e mulheres pobres e miseráveis, ao menos sob o ponto de vista financeiro.

Fig. 5. Carruagem de bispo

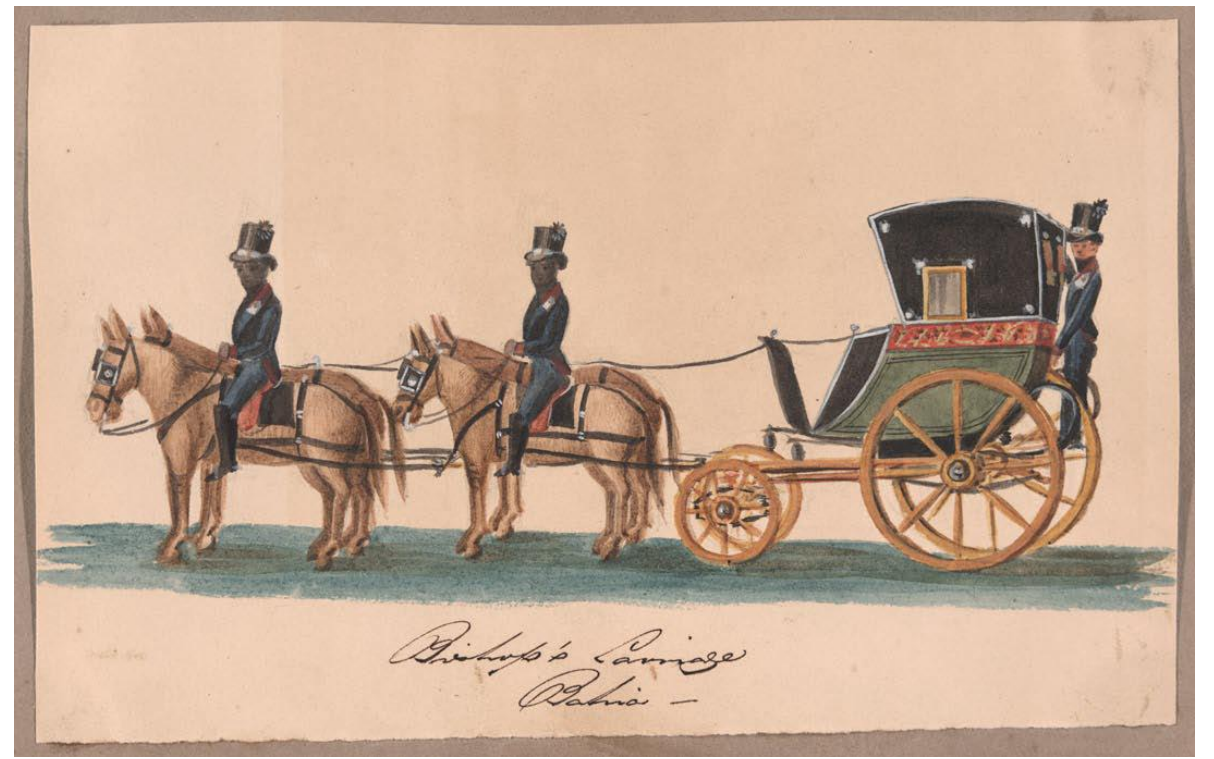

Fonte:http://bndigital.bn.gov.br/projetos/escravos/galeriagravuras.html Acesso em 07 ago. 2017. 
Na cena exposta acima se verifica que os escravos pertenciam à pessoa de posse, ou instituição poderosa, a igreja católica ou a uma autoridade desta instituição, um bispo. A igreja católica, religião oficial do Estado Monárquico, nem sempre se opôs à exploração da mão-deobra escrava, aliás, utilizou-se, em larga escala, em mosteiros, conventos, abadias, casas de misericórdia e colégios religiosos.

A maioria das ordens religiosas possuíam escravos beneditinos, capuchinhos, jesuítas, dentre outras. Ou seja, ordens religiosas e também ordens terceiras se beneficiaram intensamente da força de trabalho dos escravos contribuindo para os estigmas da escravidão brasileira que pesa sobre o africano e seus descendentes. Contudo, como se vê na gravura os escravos apresentavam mais bem vestidos e pela postura receberiam um certo "treinamento" para conviver com os cléricos das ordens religiosas. São suposições legitimas e inferências possíveis. No entanto, o cativo exerceu atividades laborativas públicas e privadas e os viajantes retrataram esse aspecto com riqueza de detalhes, especialmente, Jean Baptiste Debret.

\section{Vida doméstica: o universo do trabalho na privacidade e intimidade}

A força de trabalho do escravo(a) no século XIX pode ser verificada tanto na vida pública como na vida doméstica. Os escravos realizavam toda sorte de atividades produtivas engomadeiras, passadeiras, cozinheiras, amas-de-leite, cocheiros, camareiros, entre outras para proporcionar comodidade e conforto aos seus senhores. A vida cotidiana dos escravos domésticos nem por isso era mais fácil ou menos penosa, pois, muitas vezes, estavam entrelaçados em redes de intrigas e vilezas da vida familiar brasileira da época. Os viajantes estrangeiros retrataram com vivacidade a vida intima e a privacidade das famílias de posse do século dezenove bem como a vida doméstica de homens e mulheres pobres, as condições de vida e trabalho variaram muito de uma casa abastada para uma residência modesta.

Jean Baptiste Debret retratou com argucia a vida doméstica dos escravos do Rio de Janeiro do início do século XIX. Uma série de gravuras custodiadas pela Biblioteca Nacional referente aos anos de 1835 e 1839 demonstra esse olhar atento sobre a vida cotidiana da família brasileira, especialmente, acerca da presença do escravo no interior dos lares cariocas. Não somente Debret, mas Rugendas e tantos outros viajantes lançaram mão de seu talento e engenho para registrar com cores vivas as cenas da escravidão urbana no Brasil.

Imagens como "Une dame brésilienne dans sons interieur" é reveladora dessa convivência intima entre livres e escravos, contudo, como já salientei isso não implicava um 
igualitarismo, um relacionamento harmonioso e muito menos a quebra das relações de mando e domínio inerentes à escravidão. A imagética produzida por Debret revela e oculta. Revela que livres e escravos compartilhavam pobreza e riqueza, mas oculta as tensões que prevaleciam nessas relações. Pode-se notar na gravura abaixo essa revelação e esse ocultamento:

Fig. 6. Une dame brésilienne dans sons interieur ${ }^{2}$

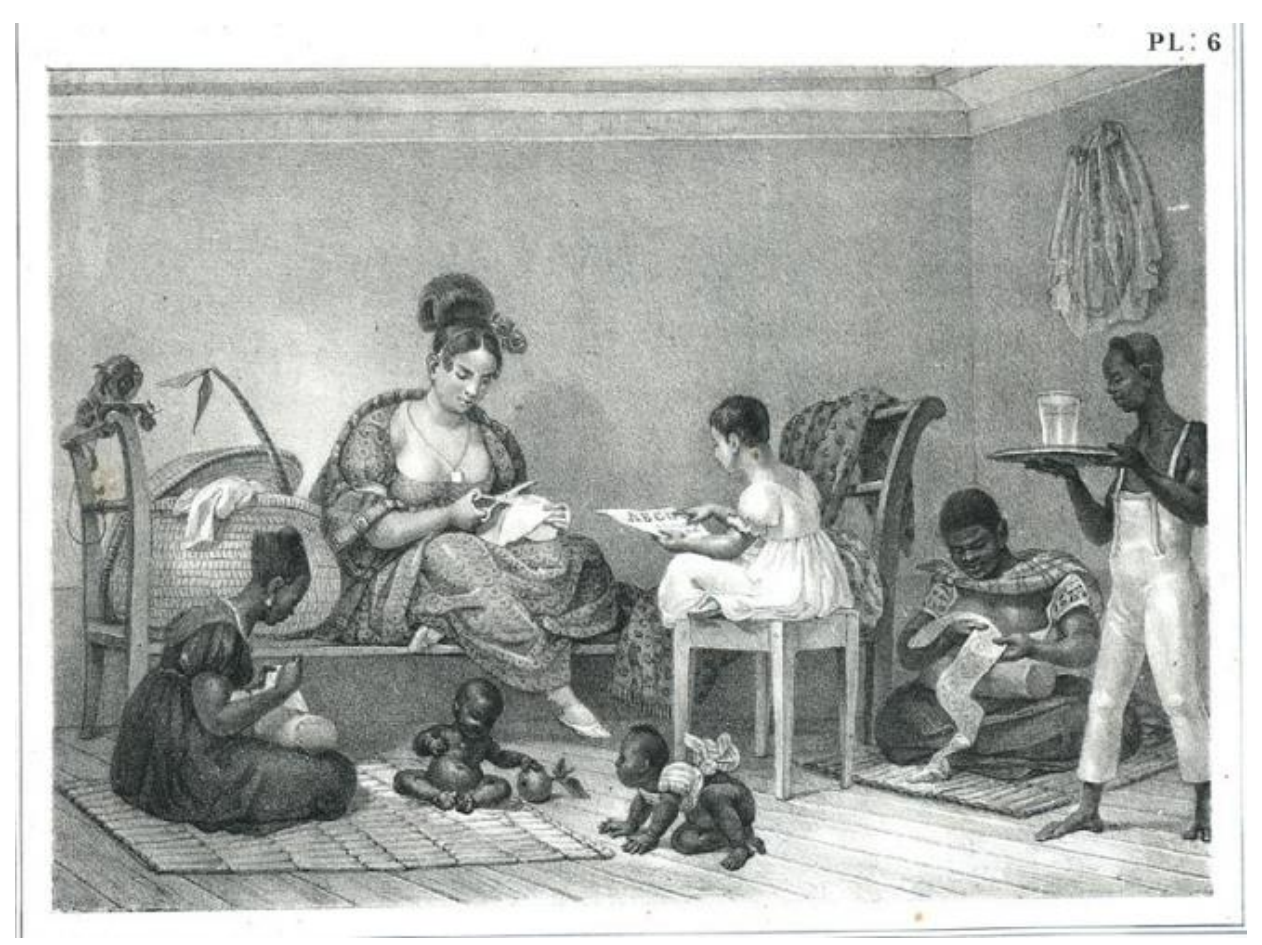

Fonte:http://bndigital.bn.gov.br/projetos/escravos/galeriagravuras.html Acesso em 07 ago. 2017

Há nessa gravura alguns aspectos peculiares que desnudam as relações hierárquicas entre livres e cativos: os escravos estão sentados no chão ou servindo. As crianças cativas estão nuas, em contraposição com a criança branca que está vestida e realiza uma leitura, enquanto a menina escrava trabalha e as duas crianças "brincam". Este é um dos aspectos das imagens de que não se pode esquecer quando se realiza um estudo como esse: as imagens são uma representação do "real", mas não o real, em si. Às vezes, inclusive, essas imagens eram criadas e produzidas em estúdios com "modelos" ou então eram encomendadas pela elite letrada das grandes cidades do Brasil oitocentista. Este ensaio apresenta apenas alguns flashes da vida cotidiana dos cativos de Recife e do Rio de Janeiro.

\footnotetext{
${ }^{2}$ Em tradução livre: Uma mulher brasileira em seu interior.
} 


\section{Urbanidade, espaços públicos e sociabilidade: praças, largos e ruas}

As cidades se constituíam em espaços públicos que necessitavam ser ocupados, eram locais onde circulavam homens e mulheres livres e cativos em mútua troca de experiências cotidianas. Varias gravuras retratam esses espaços e a convivência intensa entre ricos e pobres, negros e brancos, escravos, livres e libertos na cidade do Rio de Janeiro durante os oitocentos. A urbanidade se constituía em um espaço público de sociabilidade e convivialidade em que todos compartilhavam suas vivencias e experiências sociais.

Cada espaço público impunha suas regras e se destinava a fins diferenciados, mas todos permitiam essas trocas sociais, diálogos e comprometimentos que criavam laços entre os sujeitos históricos. Esses espaços públicos podiam ser franqueados a todos ou apenas a alguns, isto é, a cidade possuía espaços restritos às elites econômicas e sociais, como destacou Maria Nizza Beatriz da Silva (2006), mas havia espaços no seio da urbanidade de que todos desfrutavam como as praças públicas, os largos, os pequenos e grandes mercados, e as ruas comerciais.

O gravurista Luís Schlappriz deixou-nos imagens que sugerem esses espaços públicos como espaços de sociabilidade no seio da cidade do Recife, na província de Pernambuco. O artista retratou a cidade entre os anos de 1863 e 1868, contudo, é importante lembrar que havia assimetrias no interior desses espaços públicos e que o fato de todos estarem retratados não implicava o nivelamento social apenas que as pessoas conviviam e partilhavam desses espaços.

A gravura "Vista do Pateo da Penha (mercado de verduras)" deixa entrever inúmeras micro-cenas do cotidiano dos pequenos comerciantes daquela localidade da cidade, nota-se particularmente a presença das chamadas negras de ganho, ou escravos(as) de ganho muito comuns na vida carioca. Provavelmente, peixeiros, verdureiros, comerciantes de comidas prontas - caldos, angus, milhos cozidos - pequenos caixeiros viajantes, mascates e comerciantes que negociavam para revender depois no centro da cidade em suas quitandas e casas de verduras:

Fig. 7. Vista do Pateo da Penha (mercado de verdura) 


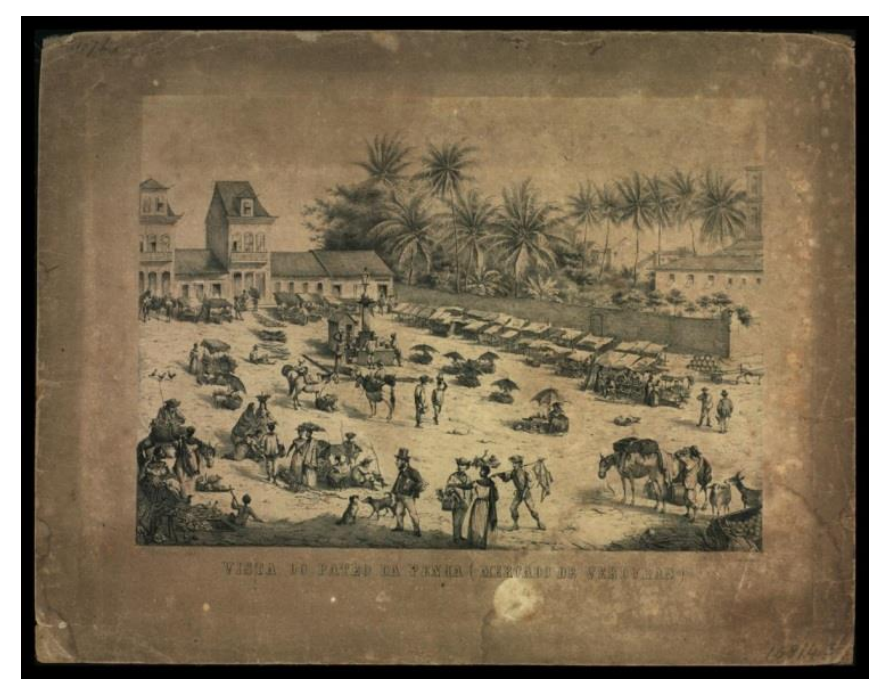

Fonte:http://bndigital.bn.gov.br/projetos/escravos/galeriagravuras.html Acesso em 07 ago. 2017.

Ao observamos em detalhe podemos notar a presença de animais - cães, cavalos, burros, galinhas, bois, entre outros animais domésticos. Verifica-se com clareza que estamos num país tropical ou de clima quente, pois há muitos guarda-sóis que protegem os comerciantes, vê-se ainda que há grupos que conversam animadamente outros expõem seus produtos outros compram e vão embora do mercado, enfim, a cena geral apresenta intensa movimentação, intercambio e conversação entre os mercadores e escravos de ganho, cabe destacar ainda nesta bela cena a existência de um outro ponto de encontro e espaço urbano de sociabilidade o chafariz ao centro da gravura.

Podemos notar ainda que o "Pateo da Penha" localiza-se atrás de alguns casarões e que o espaço amplo permitia que as negociações se prolongassem noite a dentro, pois notamos que no chafariz há um lampião a querosene ou óleo de baleia, muito comum na época. Quantos namoricos, paqueras, tramas e confusões e quantas micro histórias não terão acontecido nesse mercado.

Luís Schlappriz, em outras gravuras do mesmo período, retrata outros espaços de sociabilidade do Recife em que se vê homens e mulheres partilhando e convivendo, especialmente no âmbito das relações comerciais, expectativas, esperanças, sonhos e negócios no seu dia-a-dia. Em sua gravura "Vista do Pateo do Carmo", o pintor procurou fixar aspectos da vida cotidiana das grandes cidades do Brasil oitocentista - a Igreja, a lide comercial, a frugalidade e a convivência entre livres e escravos - enfim, procurou retratar um espaço público revelador da vida do recifense da época. Podemos ver o namoro discreto de um casal, a conversa e o passo apressado de dois cléricos, o diálogo entre dois senhores de escravos acompanhado 
de sua escrava, escravos carregadores, um carreiro de bois parado aguardando alguma mercadoria, enfim, a faina diária de uma praça comercial:

Fig. 8. Vista do Pateo do Carmo

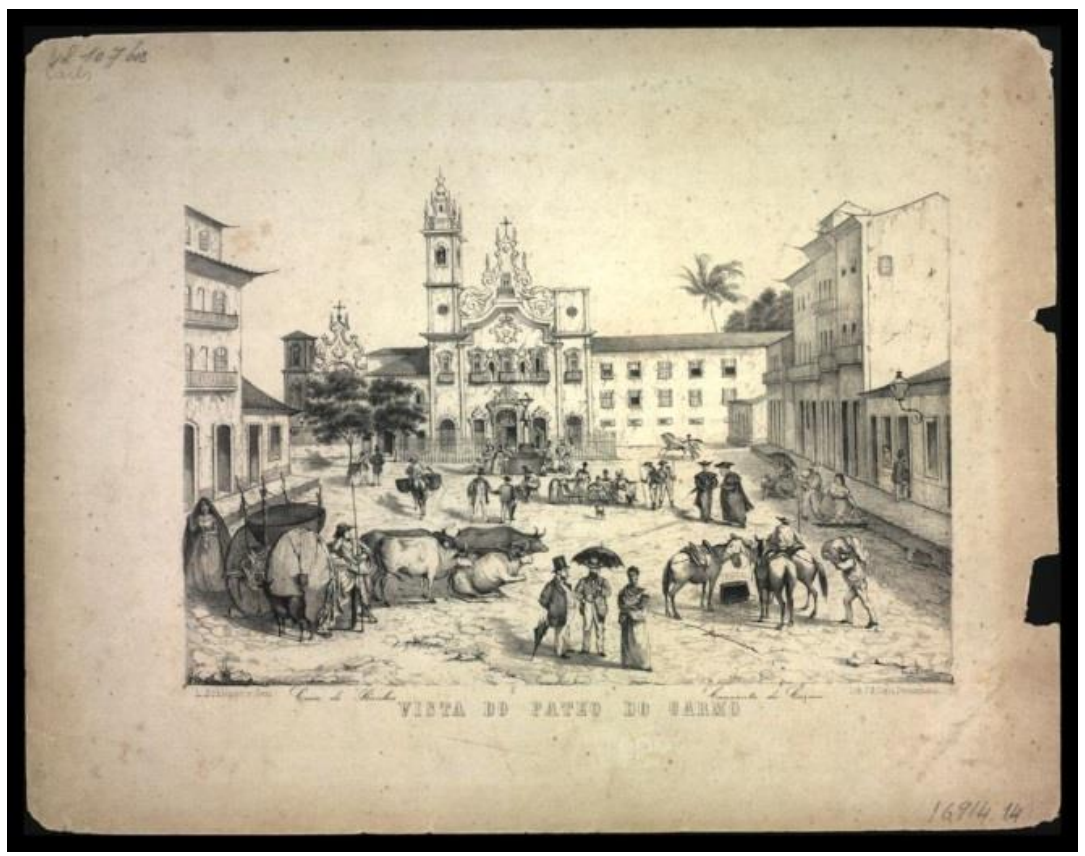

Fonte:http://bndigital.bn.gov.br/projetos/escravos/galeriagravuras.html Acesso em 07 ago. 2017

A história da escravidão e da vida cotidiana dos escravos muito se beneficia do trabalho realizado pelos gravuristas e pintores dos oitocentos, mas há ainda um estudo por fazer: o da arquitetura das grandes cidades do Brasil oitocentista. Não é o nosso proposito aqui realizar esse estudo, mas a titulo exemplificativo note-se o casario, a igreja, os prédios e outros detalhes paisagísticos e urbanísticos que contribuíam muito para a urbanidade e sociabilidade das grandes cidades abrindo espaços agradáveis, de bem viver e de conforto público aos moradores das cidades brasileiras da época, mas, sobretudo, demonstra o avanço da nossa arquitetura e paisagismo no século XIX, um estilo, um modelo de habitação que os historiadores da arquitetura precisam resgatar, inclusive, para compreendermos melhor a vida urbana das classes médias e dos homens e mulheres pobres.

Schlappriz retratou ainda outras paisagens urbanas em que circulavam os recifenses na segunda metade do século XIX, como o "Largo da Alfandega". Estamos diante de uma cena da cidade belíssima, além da arquitetura e paisagismo da cidade, vemos nesta cena o burburinho e intenso vai-e-vem de uma zona comercial portuária. O gravurista procurou fixar espaços de 
sociabilidade em que os comerciantes, pequenos e grandes, e a população trabalhadora livre e cativa circulavam e convivia naquela época.

Fig. 8. Largo da Alfandega

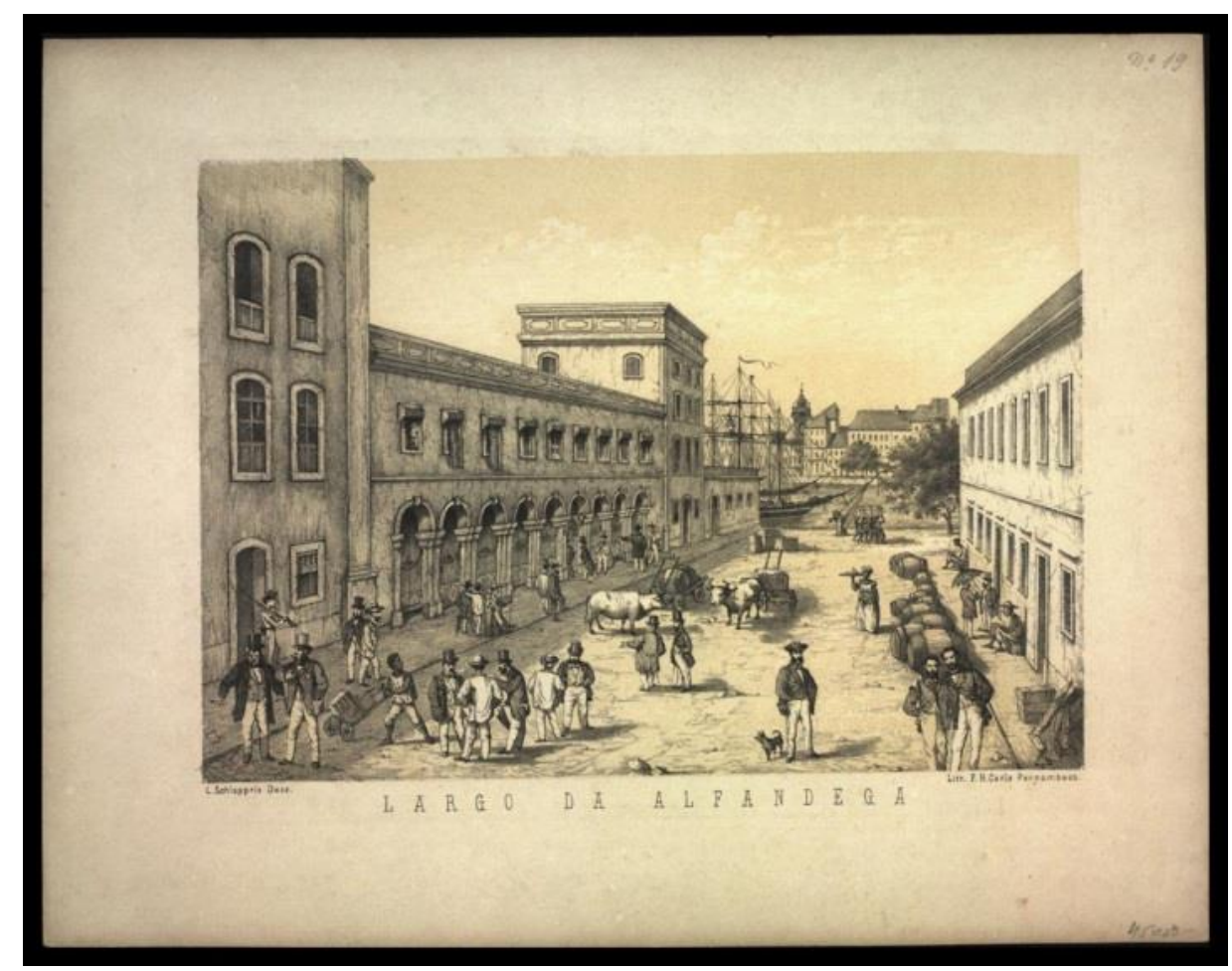

Fonte:http://bndigital.bn.gov.br/projetos/escravos/galeriagravuras.html Acesso em 07 ago. 2017

Tão rico detalhe se vê nesta gravura de 1863/68 desde os trajes dos transeuntes, as atividades que os trabalhadores executam; as conversações que se entabulam entre alguns homens - mais bem trajados - a presença de escravas de ganho; de um soldado - o olhar vigilante do Estado Monárquico constitucional - os tradicionais carros-de-bois, dos primeiros meios de transporte de mercadorias do Brasil colonial, enfim, constrói com argucia o gravuristanarrador a cena da zona comercial portuária e sua intensa movimentação diária.

O espaço de sociabilidade por excelência são aqueles em que se festejam, em que se realizam grandes comemorações publicas, em que se somam musica, dança e animadas conversas seja em espaço publico ou particular, porém, a sociabilidade de se trata aqui é aquela que envolve o citadino, o homem nos espaços públicos das grandes cidades do Brasil. O gravurista Luís Schlappriz retratou esse espaço magistralmente na gravura: 
Fig. 9. Hospital Portuguez, no dia do seo aniversario

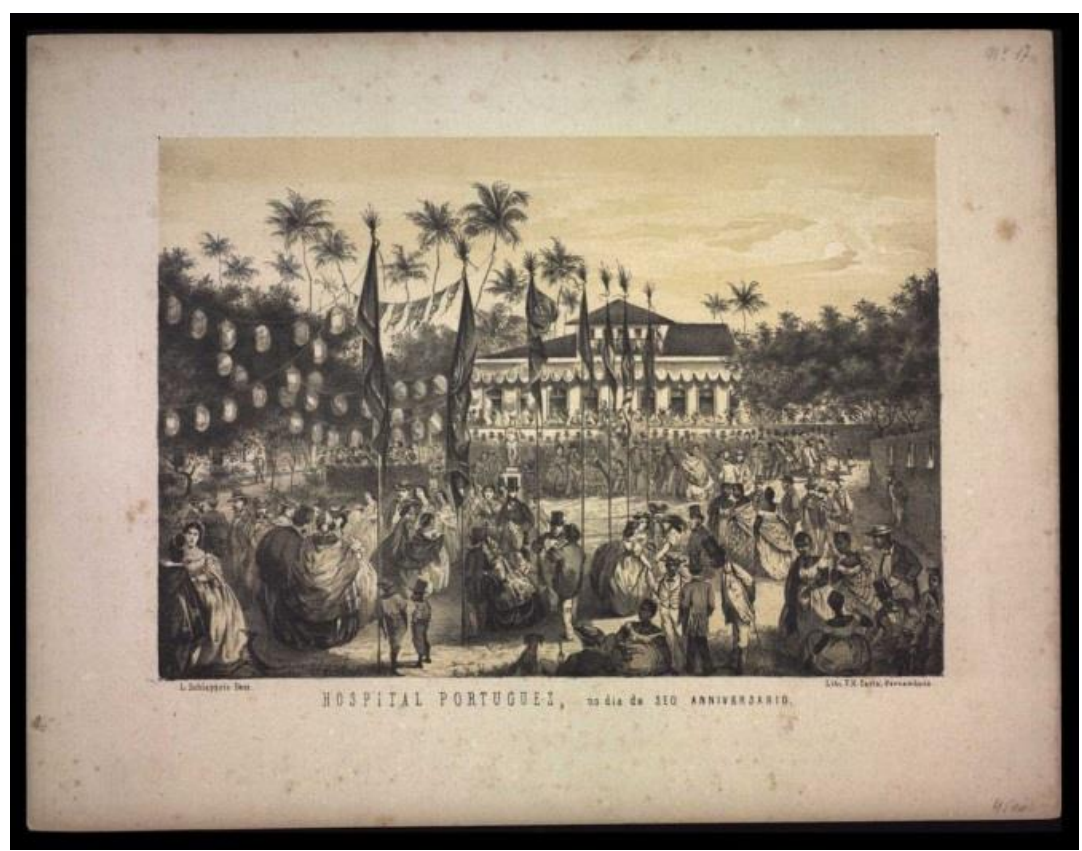

Fonte:http://bndigital.bn.gov.br/projetos/escravos/galeriagravuras.html Acesso em 07 ago. 2017

Quase, por um exercício de imaginação histórica, se pode ouvir o burburinho, os cochichos, as fofocas, as negociações e negociatas, as conversas, as paqueras, a animada música, os discursos eloquentes e tudo mais que se passa num espetáculo desta natureza, numa festa. A festa é espaço de extravasamento, de transbordamento e de inversão de papeis, como descreveu o professor (MATTA, 1987, p. 90-136), em diversas de suas obras. Nesta gravura podemos observar tudo isso e muito mais.

Vê-se neste espetáculo a multidão variada de pessoas de todos os matizes, cores, classes e status social. As diferenças se apresentam tanto nas vestimentas como nas posições ocupadas pelas pessoas na cena. Observa-se também que ganha destaque as bandeiras ao centro e ao fundo o prédio do Hospital Português. Percebe-se a rica decoração que foi preparada para a ocasião, a festa pública é essencialmente ostentatória, é uma demonstração de riqueza, prestigio e poder da classe senhorial. Pode-se verificar a posição dos negros livres e cativos: estão sempre à margem da gravura, ou quando se apresentam no centro estão realizando alguma atividade laborativa.

Percebe-se que é uma comemoração distinta, pois os homens usam trajes a rigor e as mulheres vestidos de noite ou trajes de gala, mesmo os homens pobres livres e libertos procuraram se portar e vestir em conformidade com a ocasião, é um desfile de "bom gosto" cartolas, fraques, casacas, e contra casacas, ternos e chapéus, tiaras, joias e outros adornos que 
revelam o status social dos grupos e classes sociais representados na cena, é a ocasião de demonstração publica de poder da classe senhorial, diferente dos bailes de corte ou festas reservadas em casas particulares, como bem destacou (SCHWARTZ, 2001).

\section{Considerações finais}

Ao analisarmos algumas imagens produzidas pelos viajantes e gravuristas nacionais particularmente Jean Baptiste Debret, Juan Moritz Rugendas, Luís Schlappriz, Julião Carlos constatamos um universo social rico e multifacetado, entreabrindo um quadro de reflexões que fogem ao binômio senhor-escravo e a violência inerente à essa relação, sem contudo negar a violência, a desigualdade e as assimetrias implícitas nessas relações de poder.

A reflexão desenvolvida, a partir das obras desses artistas, flagrou ou descortinou escravos, homens pobres livres, libertos e membros da elite senhorial em circunstancias sociais de convivialidade, privacidade e sociabilidade que, geralmente, não retém o olhar e a atenção da historiografia que trata da escravidão brasileira. Assim, lançou-se vistas sobre os escravos em cenas cotidianas no mundo do trabalho, em espaços públicos, privados e domésticos, bem como se observou esses agentes sociais em espaços públicos abertos como praças, mercados e "pateos", em momentos de sociabilidade pública.

A discussão e descrição das imagens procurou delindar as formas de vestir, a posição social ocupada, as formas de trabalhar e produzir e, especialmente, as diversas atividades laborais exercidas pelos escravos no Brasil dos oitocentos nas grandes cidades brasileiras como a cidade do Rio de Janeiro da primeira metade e a de Recife na segunda metade do século XIX. Destacamos que há uma imensa riqueza de detalhes sobre a arquitetura e o paisagismo brasileiro que precisam ser estudados e que os artistas do século XIX podem abrir fecundas possibilidades de analise deste patrimônio arquitetônico brasileiro.

A analise das imagens legadas pelos viajantes demonstra a visão que a sociedade oitocentista possuía do africano e seus descendentes. Estas encenações mostram a posição social ocupada por livres e escravos, as relações de poder que foram se construindo ao longo da consolidação do Estado-nação. As cenas não devem ser tomadas como "reais", mas como possíveis. Considerando que, como já se disse, poderiam ser montagens de estúdio ou apenas idealizações a partir de narrativas que o viajante ouviu dos moradores destas grandes cidades do Brasil, 
De qualquer modo, a narrativa visual herdada dos viajantes estrangeiros que viveram, passaram ou estiveram no Brasil na primeira e na segunda metade do século XIX muito contribui para o conhecimento histórico da realidade brasileira seja ela de fato ou apenas imaginada, pois ao imaginar o viajante europeu construiu possibilidades e as plasmou sobre a tela, fixando com cores vivas as cenas da escravidão brasileira e o cotidiano dos escravos nas grandes cidades do Brasil oitocentista.

\section{Referências}

ANTONIL, André João. Cultura e opulência do Brasil. 3. ed. Belo Horizonte: Itatiaia: Edusp, 1982 (Coleção Reconquista do Brasil).

BELLUZO, Ana Maria de Moraes. Brasil dos viajantes. São Paulo: Metalivros, 1995.

BOURDIEU, Pierre. O poder simbólico. Trad. Fernando Tomaz. Rio de Janeiro: Bertrand Brasil S.A., 1989.

CHARTIER, Roger. História cultural: entre práticas e representações. Trad. Maria Manuela Galhardo. 2. ed. Rio de Janeiro: Bertrand Brasil S.A., 2002.

http://bndigital.bn.gov.br/projetos/escravos/introducao.html Acesso em 07-08-2017

http://bndigital.bn.gov.br/projetos/escravos/galerias.html Acesso em 07-08-2017

http://bndigital.bn.gov.br/projetos/escravos/galeriagravuras.html Acesso em 07-08-2017

MATTA, Roberto da. Carnavais, malandros e heróis: para uma sociologia do dilema brasileiro. 6. ed. Rio de Janeiro: Rocco, 1997.

SCHWARTZ, Lilia Moritz. Viajantes em meio ao Império das festas. In: JANCSÓ, István, KANTOR, Iris. Festa: cultura e sociabilidade na América Portuguesa. vol. II. São Paulo: Hucitec: Edusp: Fapesp: Imprensa Oficial, 2001.

SILVA, Maria Nizza Beatriz da. A idade d'ouro do Brasil e as formas de sociabilidade baiana. In: NEVES, Lúcia Maria Bastos Pereira das, MOREL, Marco., FERREIRA, Tânia Maria Bessone da C. (Orgs.). História e imprensa: representações culturais e práticas de poder. Rio de Janeiro: DP\&A: Faperj, 2006. 